\title{
Identification of a Major Heparin-Precipitable Protein in Human Serum and Its Relationship to Cystic Fibrosis
}

\author{
RITA MARGOLIES, BRUCE GRAY, AND THOMAS F. BOAT ${ }^{(2.5)}$ \\ Department of Pediatrics, Case Western Reserve University, Cleveland, Ohio, USA
}

\section{Summary}

Heparin binding to serum proteins and their subsequent precipitation is reportedly increased in cystic fibrosis (CF). We have confirmed this finding for CF patients over the age of 12 [11.34 $\pm 2.42 \mathrm{mg} / \mathrm{ml}$ precipitated protein for normals $(n=19)$ versus $17.46 \pm 4.60 \mathrm{mg} / \mathrm{ml}$ for CF patients $(n=37), P<0.001 ; 0.629 \pm$ $0.098 \mathrm{mg} / \mathrm{ml}$ precipitated heparin for normals versus $0.789 \pm 0.206$ for $C F$ patients, $P<0.01$ ]. We have also shown that patients with a variety of pulmonary diseases unrelated to $C F$ do not show this effect. When the amounts of protein and heparin precipitated are compared with the amount of IgG found in the whole serum sample, the correlation coefficients (protein $r=0.77$; heparin, $0.74 ; n=81$ ) are significant at a level of $P<0.001$. In addition, the report that young $C F$ patients exhibit hypogammaglobulinemia prompted us to examine serum samples from CF patients and agematched controls under the age of 12 . No differences were found.

To investigate the molecular basis for this effect, sera from patients with $\mathrm{CF}$ and from age-matched controls were precipitated with $50 \mathrm{mg} \%$ heparin at pH 5.57 . Pellets resolubilized in $8 \mathrm{M}$ urea were fractionated on DEAE-Sephadex and analyzed by doubleimmunodiffusion, SDS-PAGE, immunoelectrophoresis, and radial immunodiffusion. IgG constituted $55-56 \%$ of the eluted protein. When serum from all donors was fractionated by Staph A-Sepharose into IgG and non-IgG fractions, $85-89 \%$ of heparin precipitable protein was in the IgG fraction.

\section{Speculation}

We conclude from this study that the major heparin-precipitable protein in human serum at pH 5.57 is IgG. The increased amounts of protein precipitated from serum of older patients with cystic fibrosis merely reflects the elevated levels of IgG in their serum. These findings do not support the hypothesis of Pearson and Lubin (16) that a generalized defect in protein glycosylation is the basis of the heparin effect, although a specific alteration of IgG oligosaccharides is not ruled out. In addition, this study of the heparin effect does not provide any evidence that there is an alteration in glycoprotein:glycosaminoglycan interaction in cystic fibrosis.

Cystic fibrosis (CF) is the most common genetic disorder among Caucasians in the United States, with an estimated incidence of one in every 2000 live births. It is widely accepted that CF is inherited as an autosomal recessive trait, and thus a defect in a single protein is to be expected.

Pearson and Lubin (15) have reported that precipitates formed by addition of heparin at $\mathrm{pH} 5.57$ to $\mathrm{CF}$ sera have higher protein and heparin contents than precipitates formed in control sera. In addition, they reported that serum proteins from patients with cystic fibrosis had increased heparin-precipitating capacity. In a later paper (16), the same authors confirmed these findings and reported altered carbohydrate composition for glycoproteins precipitated from CF serum.
These findings prompted us to identify the proteins precipitated from CF and control sera by heparin at $\mathrm{pH}$ 5.57. The literature provides little information, inasmuch as most serum protein-heparin interactions have been studied at neutral or basic $\mathrm{pHs}$.

Because of its polyanionic character, we anticipated that heparin would interact most strongly with positively charged serum proteins, i.e., the gamma globulins. IgG, which represents the bulk of this class of proteins, is elevated in serum samples from many patients with cystic fibrosis $(12,13,18,21)$. Matthews et al. (12) and Weeke et al. (21) both report that this elevation of serum IgG is correlated with severity of disease.

The results of this study show that $\operatorname{IgG}$ is indeed the major protein precipitated by heparin at $\mathrm{pH} 5.57$ and suggest that precipitation of increased amounts of $\mathrm{IgG}$ is largely responsible for previous observations of heparin interactions with $\mathrm{CF}$ serum components.

\section{MATERIALS AND METHODS}

Specimens. Nonfasting venous blood samples were allowed to clot at $4^{\circ} \mathrm{C}$. Following centrifugation, the serum was removed, aliquoted into plastic tubes (Falcon 2054), and stored for varying periods at $-70^{\circ} \mathrm{C}$. Samples were obtained with informed consent. The protocol was approved by the Human Experimentation Committee of University Hospitals.

Subjects. The patients in this study were diagnosed as having CF by clinical criteria and elevated sweat chloride concentrations. Severity of disease was graded using the clinical scoring method outlined by Doershuk, et al. (3). For this study, patients with scores over 75 are considered to have mild disease; $75-50$, moderate disease; and less than 50 , severe disease. The control population consisted of normal healthy volunteers and of patients with non-CF related pulmonary diseases. A detailed description of the subjects used in each study is provided in the appropriate sections.

Materials. Porcine heparin (Grade I) and Staph A-Sepharose were obtained from Sigma Chemicals. IgG Quantiplate kits were obtained from Kallestad and DEAE-Sephadex from Pharmacia. Prepoured immunoelectrophoresis plates were obtained from $\mathrm{Ma}$ loy. Spectropor dialysis tubing (molecular weight cutoff: 60008000 ) was used throughout. Reagents for polyacrylamide electrophoresis were supplied by Eastman.

Quantitation of protein and heparin. The amount of heparin precipitated was quantitated indirectly by measuring the amount of uronic acid in the pellet. The carbazole method, as modified by Bitter and Muir (1) and using glucuronic acid as standard, was employed. The \% of uronic acid (weight for weight) in the heparin used was also determined (31-33\%). Since heparin is an alternating copolymer of glucosamine and glucuronic acid, the amount of heparin in the precipitate could be calculated.

Protein was determined by the method of Lowry et al. (10) except when assaying the DEAE-Sephadex column fractions. In this case, the fluorescamine assay of Udenfriend et al. (20) was used because of its greater sensitivity. Bovine serum albumin was 
used as standard, except for the Staph A experiment where bovine IgG was used because this was the class of protein being studied.

Heparin precipitation of serum protein. The method of Pearson and Lubin (15) was employed for the precipitation of serum proteins with heparin at $\mathrm{pH} 5.57$. Briefly, $1 \mathrm{ml}$ of serum was added to $30 \mathrm{ml}$ of $50 \mathrm{mM}$ ammonium acetate buffer, pH 5.5 containing $0.5 \mathrm{mg}$ of porcine heparin per $\mathrm{ml}$ (the final $\mathrm{pH}$ of this solution was $\mathrm{pH}$ 5.57). The resulting precipitate was collected by centrifugation, washed with ammonium acetate buffer, and lyophilized. The pellet was resuspended in $1 \mathrm{ml}$ of $0.5 \mathrm{M}$ sodium bicarbonate in $10 \%$ ethanol and after $\mathrm{l} \mathrm{h}$ incubation, $0.2 \mathrm{ml}$ of $3 \mathrm{~N} \mathrm{NaOH}$ was added and the incubation was continued for $30 \mathrm{~min}$., until the pellet was completely solubilized.

Analysis of unprecipitated serum proteins. In order to analyze the unprecipitated serum components, the supernatants were decanted from the protein-heparin precipitates and dialyzed against $5 \%$ $\mathrm{BaCl}_{2}$ to remove the unbound heparin (2). The heparin-barium complex was removed by centrifugation $\left(8000 \mathrm{rpm}, 4^{\circ} \mathrm{C}, 30 \mathrm{~min}\right.$.) and the supernatant was then dialyzed extensively against glass distilled water, lyophilized, and resuspended in $50 \mathrm{mM}$ barbital buffer, $\mathrm{pH}$ 8.0. This preparation is referred to as the supernatant.

$D E A E$-Sephadex chromatography. Heparin was separated from the precipitated proteins by DEAE-Sephadex chromatography. This procedure also results in the fractionation of these proteins. The protein-heparin precipitate from $1.5 \mathrm{ml}$ of serum was dissolved in $3 \mathrm{ml}$ of $50 \mathrm{mM}$ Tris- $\mathrm{HCl},(\mathrm{pH} 8.0)$ containing $8 \mathrm{M}$ urea and applied to a 1.0 by $13 \mathrm{~cm}$ DEAE-Sephadex (A-50) column that had been equilibrated with the sample buffer. After the column had been washed with $15 \mathrm{ml}$ of buffer, it was eluted with a $100 \mathrm{ml} \mathrm{NaCl}$ gradient $(0-1.0 \mathrm{M})$. Fractions of $1.15 \mathrm{ml}$ were collected at a flow rate of $0.47 \mathrm{ml} / \mathrm{min}$.

The protein content of the column fractions was monitored by following the absorbance at $280 \mathrm{~nm}$. The proteins eluted as two peaks, which were dialyzed extensively against glass distilled water, lyophilized, and then resuspended in a volume of barbital buffer equivalent to that of the original serum sample. The ionic strength of the fractions was monitored by a Radiometer-Copenhagen conductivity meter, type CDM3.

Immunoanalytical methods. Immunoelectrophoresis of column fractions was performed with $50 \mathrm{mM}$ barbital buffer, $\mathrm{pH}$ 8.0. A constant current of $25 \mathrm{~mA}$ per plate was applied and the voltage never exceeded $300 \mathrm{mV}$. "Hoat" antihuman serum antiserum (Kallestad) was used in this system. IgG was quantitated by radial immunodiffusion. Double immunodiffusion analysis was carried out by the method of Ouchterlony and Nilson (14).

Sodium dodecyl sulfate polyacrylamide gel electrophoresis (SDS$P A G E$ ). SDS, $10 \%$ polyacrylamide slab gels were used according to the method of Laemmli and Favre (7). Samples in 5\% 2mercaptoethanol and $0.5 \%$ SDS were electrophoresed for approximately $3 \mathrm{~h}$ at $4^{\circ} \mathrm{C}$ at a current of $35 \mathrm{~mA}$ per gel. Proteins were visualized using Commassie Blue R-250 stain.

Preparation of $\mathrm{IgG}$ and non-IgG serum fractions. Staph Protein A covalently coupled to Sepharose $4 \mathrm{~B}$ was equilibrated in $0.1 \mathrm{M}$ phosphate buffer, pH 7.0 at $4^{\circ} \mathrm{C}$. Columns containing $1 \mathrm{ml}$ of settled gel were poured and washed extensively with the starting buffer. Serum samples were centrifuged at $3000 \mathrm{rpm}$ for $10 \mathrm{~min}$ to remove particulate matter and a $0.5 \mathrm{ml}$ aliquot applied to each column. The columns were then washed with $30 \mathrm{ml}$ of phosphate buffer, at which point the eluant no longer absorbed at $280 \mathrm{~nm}$. The IgG fraction was then eluted with $6 \mathrm{ml}$ of $1 \mathrm{M}$ acetic acid. Both fractions were immediately dialyzed against glass distilled water and lyophilized. The fractions were resuspended in a volume of phosphate buffer equivalent to the original serum sample volume, heparin precipitated, and analyzed for protein and heparin.

Data analysis. Students $t$ test for unpaired samples was used to determine the significance of difference between two means; 0.05 (two-tailed analysis) was used as the level of significance.

\section{RESULTS}

Analysis of serum protein-heparin precipitates. Table 1 data show that significantly more protein and heparin were precipitated from serum samples of CF subjects over the age of 12 than from agematched normal serum samples. Additionally, the protein/heparin combining ratio i.e., $\mathrm{mg}$ of protein precipitated per $\mathrm{mg}$ of heparin precipitated, was significantly higher $(P<0.01)$ in patients with CF $(22.71 \pm 5.87)$ when compared with normal controls (18.3 \pm 3.46). The concentration of IgG in CF sera was higher than in control sera.

Data from the two control groups were analyzed separately. No significant differences were found (Table 2). Thus both groups were designated as the control population for this study.

Table 3 presents an analysis of the data from older patients with $\mathrm{CF}$ according to the severity of their disease. All parameters showed significant differences when compared with the control group except the amount of heparin precipitated by serum and the IgG levels in serum of patients with mild disease.

When serum samples were studied from CF donors who were younger than age 12 and who had mild disease, no significant differences from age-matched control values were found (Table 4).

In no case was the concentration of total protein in serum significantly different between $\mathrm{CF}$ and control donors.

Characterization of precipitated serum proteins. Precipitated proteins from serum samples from ten normal individuals and nine individuals with cystic fibrosis were solubilized as described and qualitatively analyzed by immunoelectrophoresis. immunodiffusion, and SDS-PAGE.

Table 1. Heparin-protein precipitate data for donors age 12 and over $^{1}$

\begin{tabular}{lccc}
\hline & $\begin{array}{c}\text { Non-CF } \\
n=19\end{array}$ & $\begin{array}{c}\text { Cystic fibrosis } \\
n=37\end{array}$ & \\
& $(\mathrm{mg} / \mathrm{ml}$ of serum $)$ & $(\mathrm{mg} / \mathrm{ml}$ of serum $)$ & $P$ \\
\hline Protein precipitated & $11.34 \pm 2.42$ & $17.47 \pm 4.64$ & $<0.001$ \\
Heparin precipitated & $0.629 \pm 0.098$ & $0.789 \pm 0.206$ & $<0.01$ \\
IgG & $10.73 \pm 2.49$ & $13.93 \pm 3.85$ & $<0.001$ \\
\hline
\end{tabular}

' Control population, 10 healthy volunteers (six males and four females) and nine patients with non-cystic fibrosis related pulmonary disease who ranged in age from 13-30 years. Cystic fibrosis population, 37 patients (21 males and 16 females) ranging in age from 14-32 years.

Table 2. Heparin-protein precipitate data for control group according to disease state

\begin{tabular}{lccc}
\hline & $\begin{array}{c}\text { Normal } \\
n=10\end{array}$ & $\begin{array}{c}\text { Lung disease } \\
n=9\end{array}$ & \\
& $(\mathrm{mg} / \mathrm{ml}$ of serum $)$ & $(\mathrm{mg} / \mathrm{ml}$ of serum $)$ & $P$ \\
\hline Protein precipitated & $11.29 \pm 1.86$ & $11.42 \pm 3.03$ & n.s. \\
Heparin precipitated & $0.615 \pm 0.155$ & $0.646 \pm 0.077$ & n.s. \\
IgG & $9.54 \pm 2.11$ & $10.8 \pm 3.09$ & n.s. \\
\hline
\end{tabular}

${ }^{1}$ Infectious disease, four donors; bronchitis and asthma, five donors.

${ }^{2}$ Not significant, n.s.

Table 3. Heparin-protein precipitate data for $C F$ donors $1>12$ years old) according to severity of disease ${ }^{1}$

$\begin{array}{ccc}\text { Mild } & \text { Moderate } & \text { Severe } \\ n=13 & n=14 & n=10 \\ / \mathrm{ml} \text { of serum) } & (\mathrm{mg} / \mathrm{ml} \text { of serum }) & (\mathrm{mg} / \mathrm{ml} \text { of serum })\end{array}$

\begin{tabular}{|c|c|c|c|}
\hline $\begin{array}{l}\text { Protein pre- } \\
\text { cipitated }\end{array}$ & $15.34 \pm 3.35^{2}$ & $18.29 \pm 4.68^{2}$ & $19.11 \pm 5.39^{2}$ \\
\hline $\begin{array}{l}\text { Heparin pre- } \\
\text { cipitated }\end{array}$ & $0.688 \pm 0.164$ & $0.781 \pm 0.151^{3}$ & $0.932 \pm 0.254^{2}$ \\
\hline $\operatorname{IgG}$ & $11.77 \pm 3.80$ & $15.14 \pm 3.17^{2}$ & $15.28 \pm 3.75^{2}$ \\
\hline
\end{tabular}

'Levels of significance are determined by comparison with control group. Similar results are obtained if these data are compared to patients with non-cystic fibrosis related lung disease.

${ }^{2} P<0.001$.

${ }^{3} P<0.01$. 
Table 4. Heparin-protein precipitate data for donors age 11 and under

\begin{tabular}{|c|c|c|}
\hline & $\begin{array}{c}\text { Non-CF } \\
n=16 \\
\text { (mg/ml of serum) }\end{array}$ & $\begin{array}{c}\text { Cystic fibrosis } \\
n=15 \\
\text { (mg/ml of serum) }\end{array}$ \\
\hline Protein precipitated & $8.19 \pm 1.91$ & $8.51 \pm 2.95$ \\
\hline Heparin precipitated & $0.489 \pm 0.092$ & $0.397 \pm 0.154$ \\
\hline $\operatorname{IgG}$ & $8.22 \pm 1.83$ & $7.37 \pm 2.95$ \\
\hline
\end{tabular}

A

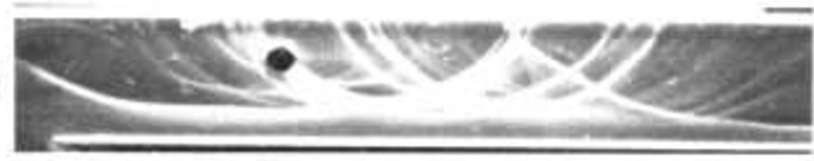

B

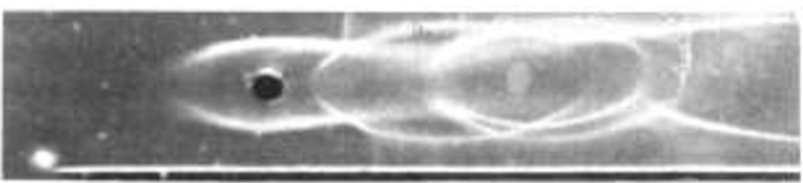

C

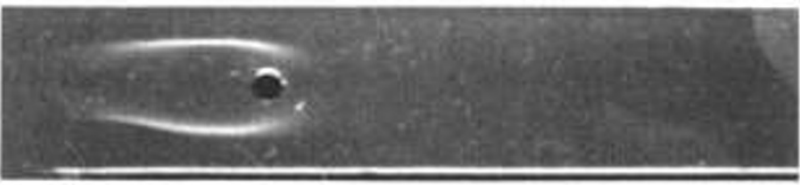

D

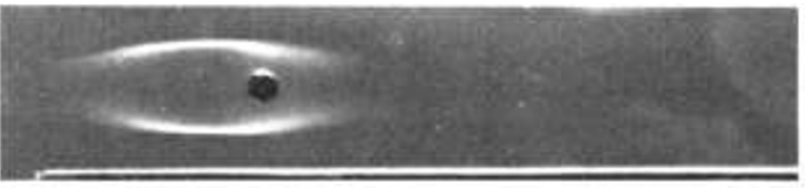

Fig. 1. Immunoelectrophoresis of $(A)$ whole serum. $(B)$ supernatant, (C) Peak 1 from DEAE fractionation of normal serum precipitate, and (D) Peak 1 from cystic fibrosis serum.
Precipitated proteins from all 19 individuals consistently eluted as two peaks. The first peak contained proteins that did not bind to the ion exchanger and was designated Peak I; the bound proteins, which were released between 5 and $25 \mathrm{mS}$, were designated Peak 2. No carbazole reacting material was found in either peak.

Immunoelectrophoresis of whole serum, Peak 1 (DEAE-Sephadex) proteins solubilized from heparin precipitate, and supernatants resulted in the migration patterns shown in Figure 1 . The most electronegative gamma globulins were strikingly absent in the supernatant fraction, but were recovered in the precipitate fraction, Peak 1 . When the Peak 2 precipitate fractions were electrophoresed, most of the precipitin bands were found in the gamma globulin region, with occasional weak bands in the beta region (results not shown). This pattern was consistent for the 5 $\mathrm{CF}$ and 5 control serum samples examined, although the bands seen with normal sera were usually weaker than those from patients with cystic fibrosis.

Double diffusion analysis of Peaks 1 and 2 from serum samples of six patients and six controls revealed the presence of IgG in both peaks. No IgM, IgA, or lysozyme were detected, although these proteins were found in the supernatant fraction. The $C 3$ component of complement was found in the supernatant and in both DEAE-Sephadex column fractions.

Column fractions from six normal individuals and six patients with CF were examined by SDS-PAGE and no qualitative differences between the two groups were found. Two protein bands that comigrated with IgG heavy and light chains were consistently found in both DEAE-Sephadex peaks of urea-solubilized precipitates. Other less prominent, but higher molecular weight protein bands appeared in Peak 2 fractions from control and CF sera. These have not been identified. Figure 2 shows a typical gel with samples from DEAE-Sephadex Peaks 1 and 2, supernatants, and whole serum from a normal donor and a CF donor.

Protein and immunoglobulin concentrations in DEAE-Sephadex fractions of solubilized precipitates were measured to determine if there were qualitative differences with respect to total protein and/or IgG content (Table 5). The total amount of protein eluting from the DEAE-Sephadex column was significantly higher for serum samples from patients with cystic fibrosis. The amount of IgG in Peak 2 was three times higher for donors with cystic fibrosis; however, because of the wide variation among individ-

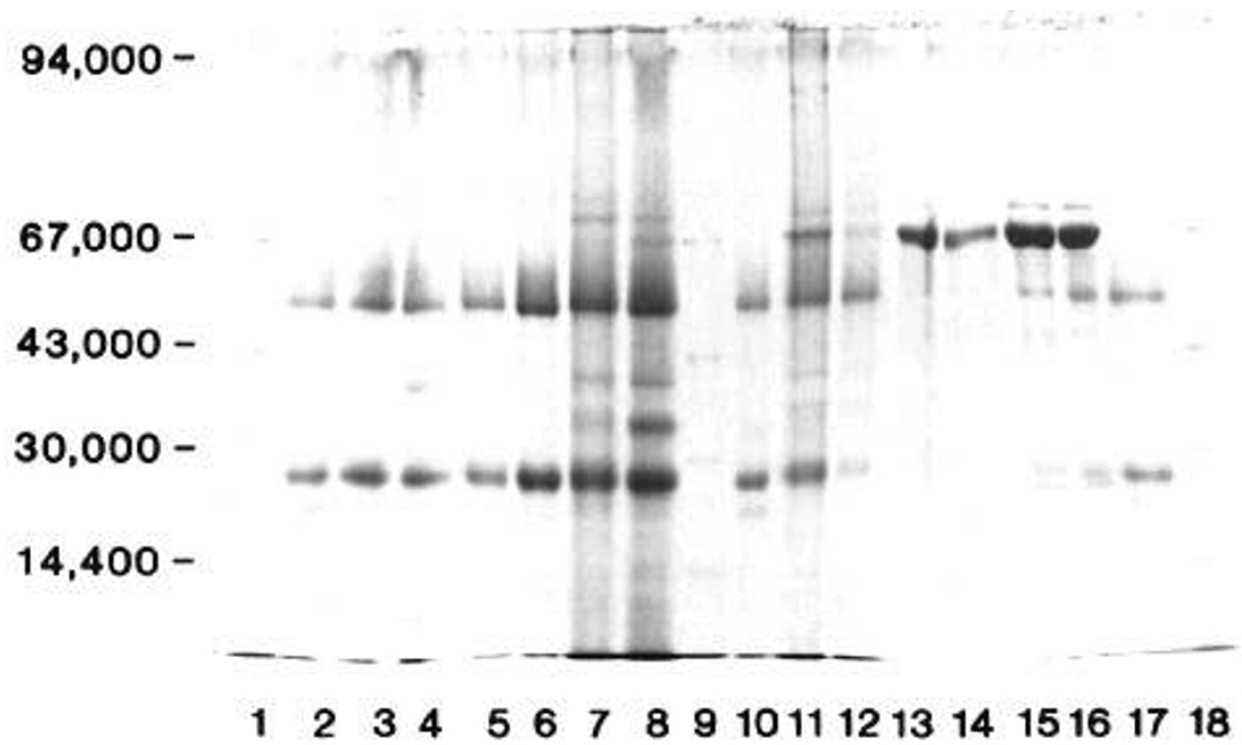

Fig. 2. Typical SDS-PAGE of DEAE-Sephadex column fractions. Lanes 1,9 , and 18 contain the standards, phosphorylase b. bovine serum albumin, carbonic anhydrase, and $\alpha$-lactalbumin. Lanes 2, 10, and 17 contain partially purified IgG as standard. Lane 3 contains Peak Ia from a normal individual, Lane 4 contains the same material from a patient with cystic fibrosis; Lane 5-Peak Ib, normal; Lane 6-Peak 1 b, cystic fibrosis; Lane 7 Peak 2a, normal; Lane 8-Peak 2a, cystic fibrosis; Lane 11-Peak 2b, normal; Lane 12-2b, cystic fibrosis; Lane 13--supernatant, normal; Lane 14supernatant, cystic fibrosis; Lane 15-serum, normal; Lane 16-serum, cystic fibrosis. All lanes contain approximately the same amount of protein. Note the faintness of the IgG bands in the supernatants. 
Table 5. Analysis of DEAE-Sephadex fractions

\begin{tabular}{|c|c|c|c|c|c|c|}
\hline & \multicolumn{2}{|c|}{ Peak 1} & \multicolumn{2}{|c|}{ Peak 2} & \multicolumn{2}{|c|}{ Total } \\
\hline & $\mathbf{N}$ & $\mathrm{CF}$ & $\mathbf{N}$ & $\mathrm{CF}$ & $\mathbf{N}$ & $\mathrm{CF}$ \\
\hline $\begin{array}{l}\text { Protein eluted (mg per } 1.5 \mathrm{ml} \\
\text { sample) }\end{array}$ & $3.27 \pm 1.61$ & $4.02 \pm 1.53$ & $1.53 \pm 1.8$ & $3.25 \pm 1.60^{1}$ & $4.80 \pm 1.80$ & $7.25 \pm 2.55^{2}$ \\
\hline IgG eluted (mg) & $2.28 \pm 1.18$ & $2.58 \pm 1.38$ & $0.32 \pm 0.42$ & $1.00 \pm 1.00$ & $2.64 \pm 1.15$ & $3.58 \pm 2.19$ \\
\hline
\end{tabular}

$' P<0.005$.

${ }^{2} P<0.01$.

Table 6. Results of heparin precipitation of protein fractions from Staph A-Sepharose chromatography ${ }^{1}$

\begin{tabular}{|c|c|c|c|c|}
\hline & \multicolumn{2}{|c|}{ Fraction A } & \multicolumn{2}{|c|}{ Fraction B } \\
\hline $\begin{array}{l}\text { Staph A fractions } \\
\text { (mg of protein) }\end{array}$ & $45.64 \pm 9.45$ & $51.69 \pm 13.3$ & $12.36 \pm 5.58$ & $16.15 \pm 5.97$ \\
\hline $\begin{array}{l}\text { Protein precipitated }{ }^{2} \\
\quad(\mathrm{mg})\end{array}$ & $0.86 \pm 0.67$ & $1.37 \pm 1.06$ & $.6 .44 \pm 2.40$ & $8.02 \pm 3.07$ \\
\hline $\begin{array}{l}\text { Heparin precipitated } \\
\text { (mg) }\end{array}$ & $0.216 \pm 0.124$ & $0.287 \pm 0.196$ & $0.897 \pm 0.417$ & $0.998 \pm 0.344$ \\
\hline
\end{tabular}

${ }^{1}$ Per ml of serum.

${ }^{2}$ Protein was determined by the method of Lowry, et al. (10) using bovine IgG as standard.

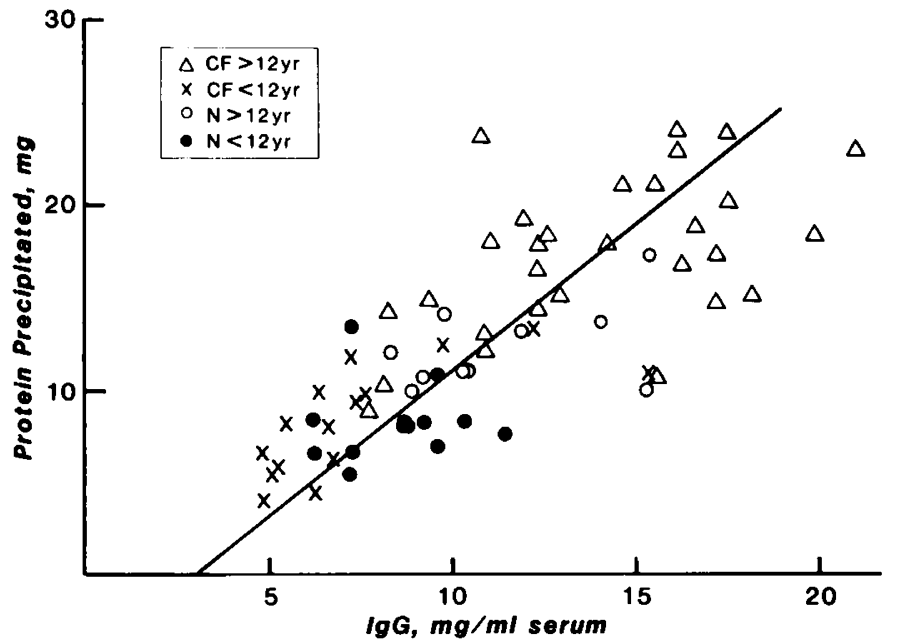

Fig. 3. A comparison between the amount of $\mathrm{IgG}$ in the serum sample and the amount of protein precipitated. The correlation coefficient is 0.77 $(n=81, P<0.001)$.

uals, these data are not statistically significant. It should also be noted that the ratio of IgG to total protein in each fraction was identical for the two groups.

Serum fractionation. In order to confirm that $\mathrm{IgG}$ is the major heparin-precipitable protein, serum samples from 10 normal and $12 \mathrm{CF}$ individuals were fractionated into non-IgG (Fraction A) and IgG (Fraction B) fractions by using Staph Protein A-Sepharose 4B to bind immunoglobulins of all subclasses except IgG3, which represents only about $5 \%$ of the total (15). The two resulting fractions were heparin precipitated and the pellets were analyzed for protein and heparin.

As can be seen from Table 6, approximately $80-85 \%$ of the precipitable protein in serum is contributed by Fraction B, which contains predominately IgG. Indeed, in some cases, virtually no precipitated protein could be detected in Fraction A.

Direct correlation of serum IgG concentrations with protein precipitation. Figure 3 shows the relationship between the amount of precipitated protein and the levels of $\operatorname{IgG}$ in whole serum from all donors. The correlation coefficient for the amount of precipitated protein and the levels of $\mathrm{IgG}$ in the serum samples is $0.77, n=81$,
$P<0.001$, and for precipitated heparin and IgG the correlation coefficient is $0.74, n=81, P<0.001$. When the correlation coefficient is computed only for older cystic fibrosis patients, the results are very similar and are still significant at a level of $P<$ 0.001 .

\section{DISCUSSION}

This study was initiated to re-examine the work of Pearson and Lubin $(15,16)$ who reported that heparin-protein precipitates from sera of cystic fibrosis patients contain both more heparin and more protein than precipitates from control sera. Our findings confirm these results with several exceptions. The amount of protein precipitated was significantly higher for serum samples from older cystic fibrosis patients regardless of the severity of disease. In addition, the protein/heparin combining ratio in our study is higher for $\mathrm{CF}$ serum samples, when compared to controls, while Pearson and Lubin $(15,16)$ reported it to be lower. The reason(s) for discrepancies between the two studies cannot be explained by procedural differences since the methods described by Pearson and Lubin were followed exactly.

We have extended these observations by demonstrating that at pH 5.57 the major heparin precipitable protein in human serum is IgG. The evidence is as follows: (1) a prominent precipitin band appears only in the gamma globulin region after immunoelectrophoresis of DEAE-Sephadex fractions from urea-solubilized heparin-protein precipitates. This band is missing in the supernate. Double immunodiffusion of the precipitate fractions shows reactivity with anti-IgG antiserum but not with anti-IgM, IgA, or lysozyme antisera; (2) SDS-PAGE of the DEAE-Sephadex fractions from solubilized precipitates (especially Peak 1) reveals major bands that comigrated with heavy and light chains of IgG; (3) over $50 \%$ of the serum protein precipitated by heparin and then eluted from DEAE-Sephadex columns was found by radial immunodiffusion to be $\mathrm{IgG}$; $(4)$ when whole serum is fractionated on Staph A-Sepharose into non-IgG and IgG fractions, 85-89\% of the total protein precipitated by heparin resides in the IgG fraction; and (5) furthermore, we have shown that increased amounts of precipitate formed in CF sera are closely correlated with elevated IgG levels.

Different values for the amount of protein in $\mathrm{NaOH}$-solubilized precipitates (Table 1), the amount of protein recovered from DEAE-Sephadex chromatography of urea-solubilized precipitates (Table 5), and the amount of protein precipitated after Staph 
Protein A fractionation (Table 6), can be attributed to the different methods of protein estimation and standards used in each of these experiments. First, when the Fluram method of protein estimation is used with bovine serum albumin as standard, the protein content of a sample containing predominantly IgG is underestimated by about $60 \%$ (unpublished data). Thus, if one corrects the data shown in Table 5 for the $60 \%$ underestimate and compares it with the data shown in Table 1 , a $66 \%$ recovery is calculated. This figure is roughly comparable with the usual recovery of IgG from DEAE (4). In addition, the measured levels of IgG in urea-treated samples may not be as high as expected because there may have been a loss of antigenically reactive IgG. Recovery data from the DEAE column are not reported because the amounts of urea and Tris required to solubilize the pellets interferes with both the Fluram and Lowry methods of protein estimation. Finally, heparin precipitation of serum fractions may not mimic precipitation from whole serum. However, this experiment did show that approximately one-half of the serum IgGs are capable of interacting with heparin and that other serum proteins are considerably less so.

There are several reports in the literature that the concentrations of IgG are elevated in many patients with cystic fibrosis, particularly in those over the age of 10. Matthews et al. (12) examined 419 patients with cystic fibrosis. They found that, compared with normals, of 178 patients $10-20$ years old, $24 \%$ had elevated serum levels while of 87 patients over the age of $20,47 \%$ had elevated levels. On the other hand, in patients under the age of 10 only $6.5 \%$ had elevated levels, while $22 \%$ had low levels. In our study, in patients over 12 , over $50 \%$ had elevated IgG levels, and only $10 \%$ had low levels compared with age-matched controls. In younger patients, this was reversed: $50 \%$ had low levels while only $13 \%$ had high levels compared with age-matched controls. In our study, protein-heparin precipitates from patients under the age of 12 also showed no differences from normals in the amount of protein or heparin precipitated. This supports our contention that increased levels of precipitable proteins are related to elevated concentrations of serum IgG.

Can the increase in heparin-precipitable protein be largely accounted for by the increase in IgG levels seen in patients with cystic fibrosis? While our studies show a mean increase in IgG levels of $3.2 \mathrm{mg} / \mathrm{ml}$, Weeke et al. (21) report that on average, patients with cystic fibrosis have an increase of $5 \mathrm{mg}$ of IgG per $\mathrm{ml}$ of serum and Schwartz (18) reports that the serum levels in older patients are increased by $6.86 \mathrm{mg} \mathrm{IgG} \mathrm{per} \mathrm{ml}$ of serum, which compares favorably with the $6.13 \mathrm{mg}$ of extra protein in precipitates of cystic fibrosis serum (see Table 1). None of the other 17 proteins examined by Weeke $e t$ al. showed an increase in CF serum samples that even approached this magnitude, except for alpha $a_{2}$-macroglobulin, which showed an average increase of $1.3 \mathrm{mg}$. The absence of any precipitin bands in the alpha globulin region on immunoelectrophoresis of the precipitated proteins is a strong indication that this protein was not precipitated to any significant degree. It is unlikely that other serum proteins, alone or in combination, contribute substantially to the heparin precipitation effect in CF serum.

One possible reason for the scatter in the data presented in Table 5 may be differences in the individual immune responses. It is well documented that the humoral response to specific types of antigens (i.e., polysaccharide, protein, etc.) is subclass restricted $(17,23)$ and that the isoelectric points of the $\mathrm{IgG}$ subclasses vary; IgGl, pI 6.8 to $<9$, IgG2, pI 6.3-8.4; IgG3, pI 8.0-9.0; IgG4, pI $<6.2$ (22). Thus the concentrations of the various subclasses can vary depending on which antigen has elicited a response. In addition, Shakib et al. (19) have reported that CF patients have altered ratios of serum IgG subclasses. Because of the electrostatic nature of the heparin-protein complex (8), changes in the relative amounts of the four IgG subclasses would be expected to affect the amount of protein and heparin precipitated.

An alternate hypothesis is suggested by Levy, et al. (9) who have demonstrated that all eight heparin-binding myeloma proteins studied had cross-reacting idiotypes not found in 92 nonhe- parin binding monoclonal IgGs. No other common feature was found, i.e., light chain type, isoelectric point, or subclass. Perhaps serum from CF patients has larger amounts of IgGs with idiotypes similar to those found by Levy, et al.

Pearson and Lubin (16) have put forth the hypothesis that "the glycoprotein biosynthetic mechanism in cystic fibrosis is genetically altered and produces glycoproteins of abnormal carbohydrate composition which combine with normal, acid glycosaminoglycans to form insoluble, viscous complexes that hinder normal cellular and subcellular transport mechanisms and metabolic processes." This hypothesis is based on the analysis of the carbohydrate composition of the protein-heparin precipitates, the results of which are as follows: a $27 \%$ decrease in sialic acid, a $27 \%$ increase in fucose, and a $31 \%$ decrease in hexose in glycoproteins precipitated from cystic fibrosis serum as compared with controls, although no differences in the carbohydrate composition of whole serum were found (16). Accordingly we are currently investigating whether the carbohydrate content of IgGs from CF serum is different from that of IgGs from normal serum.

Since we have shown that only one major class of serum proteins is precipitated by heparin, a generalized defect in glycosylation is not suggested by the altered CF serum protein-heparin interactions, although a specific alteration in $\operatorname{IgG}$ glycosylation is not ruled out. This conclusion is also supported by the work of Hunt and Summers (6), who showed that $G$ protein of vesicular stomatitis virus is normally glycosylated when grown in CF fibroblasts, and of Margolies (11), who examined the levels of fucosyland sialytransferases in CF fibroblasts and lymphoid lines and found no alterations in these enzyme activities. We suggest that the previously reported alterations of the carbohydrate content may reflect differences in the IgG subclass distribution in CF (19).

Our observations also make a generalized alteration in glycoprotein: glycosaminoglycan interaction an unlikely explanation for the heparin effect first described by Pearson and Lubin (16). However, serum-type glycoproteins are synthesized by a mechanism entirely different from that of mucous-type glycoproteins ( 5 , 20). Therefore failure to uncover abnormalities of serum glycoproteins does not preclude alterations of mucous glycoprotein synthesis or metabolism in CF.

\section{REFERENCES AND NOTES}

1. Bitter, T and Muir, H. M.: A modified uronic acid carbazole reaction. Anal. Biochem., 4: 330 (1962).

2. Burstein, M., Scholnick, H. R., and Morfen, R.: Rapid method for the isolation of lipoproteins from human serum by precipitation by polyanions. J. Lipid Res., 11: 583 (1970).

3. Doershuk. C. F., Matthews, L. W., Tucker, A. S., Nudelman. H., Eddy. G., Wise M., and Spector, S.: A 5-year clinical evaluation of a therapeutic program for patients with cystic fibrosis. J. Pediatr., 65: 677 (1964).

4. Fahey, J. L.: In: C. A. Williams and M. W. Chase: Methods in Immunology and Immunochemistry, Vol. I, p. 321 (Academic Press, New York, 1974).

5. Hanover, J. A., Lennarz, W. J., and Young. J. D.: Synthesis of N- and O-linked glycopeptides in oviduct membrane preparations. J. Biol. Chem., 255: 6713 (1980).

6. Hunt, L. A. and Summers, D. F.: Glycosylation of VSV glycoprotein is similar in cystic fibrosis, heterozygous carrier, and normal human fibroblasts. J. Supramol. Struct., 7: 213 (1977).

7. Laemmli, W. K. and Favre, M.: Maturation of the head of bacteriophage T4. J. Mol. Biol. 80: 575 (1973).

8. Laurent, T. C.: Interaction between protein and glycosaminoglycans. Fed. Proc.. 36: 24 (1977).

9. Levy, D. E., Horner, A. A., and Solomon. A.: Immunoglobulin-sulfated polysaccharide interactions. Binding of agaropectin and heparin by human IgG proteins. J. Expl. Med., 153: 883 (1981).

10. Lowry, O. H., Rosenbrough, N. J., Farr, A. L., and Randall, R. J.: Protein measurement with the Folin phenol reagent. J. Biol. Chem., 193: 265 (1951).

11. Margolies, R.: Ph.D. Thesis, City University of New York, 1981.

12. Matthews, W. J., Williams, M., Oliphant, B., Geha, R., and Colten, H. R.: Hypogammaglobulinemia in cystic fibrosis. N. Engl. J. Med., 302: 246 (1980).

13. McFarland, H., Holzel, A., Brenchley, P., Allen, J. D., Wallwork, E. C., Singer, B. E., and Worsley, B.: Immune complexes in cystic fibrosis, Brit. J. Med., 1 : 423 (1975).

14. Ouchterlony, O. and Nilson, L. A.: Immunodiffusion and immunoelectrophoresis. In: D. M. Weir: Handbook of Experimental Immunology, 3rd ed., p. 19.I (Blackwell Scientific Publications, Oxford, 1978).

15. Pearson, R. D. and Lubin, A. H.: A simple method for estimating a "heparin binding capacity" of human serum, Health Lab. Sci., 15(1): 32 (1978). 
16. Pearson, R. D. and Lubin, A. H.: Increased heparin binding in cystic fibrosis: A reflection of altered glycoprotein synthesis? Pediatr. Res., 13: 834 (1979).

17. Perimutter, R. M.. Hansburg, D., Briles, D. E., Nicoletti, R. A.. and Davie, J. M.: Subclass restriction of murine anti-carbohydrate antibodies, J. Immunol., 126 : 566 (1978).

18. Schwartz, R. H.: Serum immunoglobulin levels in cystic fibrosis. Am. J. Dis Child., 111: 408 (1966)

19. Shakib, F., Stanworth, D. R., Smalley, C. A., and Brown, G. A.: Elevated serum IgG 4 levels in cystic fibrosis patients, Clin. Allergy, 6: 237 (1976).

20. Udenfriend, S., Stein, S., Bohlen, P., Daerman, W. Leimgruber, W., and Weigle. M.: Fluorescamine: A reagent for assay of amino acids, peptides, proteins, and primary amines in the picomole range, Science, 178: 871 (1972).

21. Weeke, B., Flensborg, E. W., Jacobsen, L., Jorgensen, B. A., Lykkegard, E., and Hoiby, N.: Immunochemical quantitation of 18 proteins in sera from patients with cystic fibrosis. Concentrations correlated to class of fibroblast metachromasia, clinical and radiological lung symptoms. Danish Med. Bull.. 23(3): 155 (1976).

22. Williamson, A. R.: Isoelectric focusing of immunoglobulins. In: D. M. Weir: Handbook of Experimental Immunology, 3rd Ed., p. 96 (Blackwell Scientific
Publications, Oxford, 1978)

23. Young, W. J. Dorner, M. D., Kunkel, H. G., and Kabat, E. A.: Studies on human antibodies. VI. Selective variation in subgroup composition and genetic markers, J. Expl. Med., 127: 633 (1968).

24. The authors would like to thank Dr. P.-W. Cheng, Dr. L. Poncz, and Dr. R. N. Smith for their helpful suggestions. We are grateful to Dr. S. Polmar for providing us with partially purified IgG, to Dr. J. Scillian for putting antisera and equipment at our disposal, and to Dr. R. Stern for procuring blood samples.

25. Requests for reprints should be addressed to: Thomas F. Boat. Rainbow Babies and Childrens Hospital, 2101 Adelbert Road. Cleveland, $\mathrm{OH}, 44106$.

26. This research was supported by NIH Grant AM 08305. a Parker B. Frances Foundation Fellowship, and the Rainbow Chapter of the Cystic Fibrosis Foundation.

27. Presented in part at the Annual Meeting. Society for Pediatric Research, San Francisco, CA, 1981.

28. Received for publication April 16, 1981

29. Accepted for publication September 23, 1981. 